\title{
EVALUASI DAN IMPLEMENTASI SISTEM SURVEILANS DEMAM BERDARAH DENGUE (DBD) DI WILAYAH KERJA PUSKESMAS 1 DENPASAR BARAT TAHUN 2019
}

\author{
Irma Rubianti', A.A.S.Sawitri², I Ketut Gita ${ }^{3}$, Nikman Azmin ${ }^{4}$, Olahairullah ${ }^{5}$ \\ 1,4,5 Program Studi Pendidikan Biologi STKIP Bima \\ 2Dosen Ilmu Kesehatan Masyarakat Fakultas Kedokteran Universitas Udayana \\ ${ }^{3}$ Surveilance officer Dinas Kesehatan Kota Denpasar \\ (Email: biologinikman@gmail.com)
}

\begin{abstract}
Abstrak
Kota Denpasar merupakan daerah endemis DBD, dengan jumlah kasus DBD menampati urutan ke-5, dan Incidence Rate (IR) menempati urutan ke-8 di Provinsi Bali. Pencegahan dan penanggulangan DBD diupayakan dari segi preventif yaitu dengan memutus mata rantai penularan DBD, diantaranya dengan pelaksanaan surveilans. Dari hasil surveilans diharapkan bisa menekan jumlah kasus dan angka kesakitan DBD. Program tersebut dapat terlaksana dengan baik atau tidak sangat dipengaruhi oleh peran serta dari seluruh pihak seperti pejabat setempat, petugas kesehatan dan seluruh lapisan masyarakat, sehingga perlu dilakukan evaluasi pelaksanaan surveilans kasus DBD di wilayah kerja Dinas Kesehatan Kota Denpasar berdasarkan atribut surveilans. Metode evaluasi sistem surveilans dilakukan secara kualitatif meliputi input, proses, dan output, dan berdasarkan atribut surveilans. Pengembangan sistem surveilans menggunakan metode intervensi dengan mengidentifikasi, mengadvokasi, dan menbagikan formulir KD/RS DBD kepada 12 praktek dokter swasta yang ikut dalam pengembangan sistem surveilans DBD. Hasil penelitian: Dari 12 praktek dokter swasta yang harus teridentifikasi, hanya 10 dokter yang berhasil ditemukan oleh peneliti. Setelah melakukan evalusi selama 3 bulan, tidak ada satupun dokter praktek swasta yang melaporkan kasus DBD sehingga laporan kasus berjumlah o (nol). Tidak adanya kasus DBD yang dilaporkan disebabkan diantaranya adalah: pada saat membagikan formn KD/DBD kepada dokter, ada beberapa dokter yang menyatakan bahwa apabila ada kasus DBD mereka langsung merujuknya ke Rumah sakit, dan bila ditemukan suspect DBD akan disarankan melakukan pemeriksaan darah di Laboratorium, setelah itu biasanya pasien akan langsung ke Rumah Sakit. Ada juga Penyebab lainnya kemungkinan dokter tidak ada waktu karena banyaknya pasien yang harus ditangani untuk mengisi form KD/DBD dan menghubungi peneliti untuk pelaporan kasus DBD. Selain itu juga karena praktek dokter swasta merasa tidak berkewajiban untuk melaporkan kasus DBD kepada pihak puskesmas. Pengembangan sistem surveilans untuk pelaporan kasus DBD oleh praktek doktek swasta tidak berhasil dalam menjadikan data kasus DBD yang lebih akurat dan representatif. Hal ini disebabkan karena praktek dokter swasta yang berjumlah 10 orang, selama 3 bulan tidak ada yang melaporkan kasus DBD ke Puskesmas I Denpasar Bara.
\end{abstract}

Kata kunci: Evaluasi, Implementasi, Surveilans, DBD

\section{PENDAHULUAN}

Demam berdarah dengue (DBD) masih merupakan masalah kesehatan masyarakat dan menimbulkan dampak sosial maupun ekonomi. Jumlah kasus yang dilaporkan cenderung mengalami peningkatan dan daerah 
penyebarannya semakin meluas. Kerugian sosial yang ditimbulkan diantaranya berkurangnya usia harapan penduduk, kematian anggota kluarga dan kepanikan dalam keluarga (Azmin dkk, 2019). Dampak ekonomi secara langsung yang diderita oleh penderita DBD adalah biaya pengobatan, sedangkan dampak tidak langsungnya yaitu kehilangan mendapatkan obat herbal, waktu kerja, waktu sekolah dan biaya tidak terduga yg dikeluarkan selain biaya transportasi dan akomodasi selama dirawat (Azmin dan Rahmawati, 2019).

Kota Denpasar merupakan salah satu daerah endemis DBD di Provinsi Bali yang hampir setiap tahunnya menduduki peringkat pertama dalam jumlah kasus DBD. Jumlah kasus DBD selama tahun 2008 di Kota Denpasar tercatat sebanyak 3.264 orang dengan kematian sebanyak 10 orang sehingga Case Fatality Rate (CFR) sebesar 0,31\%. Tahun 2015 di kota Denpasar kasus DBD sebanyak 1.581 dengan angka kematian 14 orang, dan IR 216. Pada tahun 2016 kasus DBD 2.851 dengan angka kematian 18 orang , dan IR 434. Di Propinsi Bali, Kota Denpasar untuk kasus DBD menampati urutan ke-5, dan untuk IR menempati urutan ke-8 (Rakor Jumantik, 2017). Pencegahan dan penanggulangan DBD diupayakan dari segi preventif yaitu dengan memutus mata rantai penularan DBD, diantaranya dengan pelaksanaan surveilans. Dari hasil surveilans diharapkan bisa menekan jumlah kasus dan angka kesakitan DBD. Program tersebut dapat terlaksana dengan baik atau tidak sangat dipengaruhi oleh peran serta dari seluruh pihak seperti pejabat setempat, petugas kesehatan dan seluruh lapisan masyarakat.

Kegiatan surveilans DBD di Kota Denpasar, diantaranya yang dilakukan di Puskesmas I Denpasar Barat dimana data tersangka DBD (Demam Berdarah Dengue) dan penderita DD (Demam Dengue), DBD, SSD (Sindrom Syok Dengue) yang diterima puskesmas hanya berasal dari Puskesmas sendiri, Rumah Sakit dan Dinas Kesehatan Kota, sedangkan pelaporan dari unit pelayanan kesehatan lain (dokter praktek swasta, poliklinik, dan lain-lain) belum ada. pengumpulan data juga berasal dari penyelidikan epidemiologi (PE) yang dilakukan oleh jumantik. Pengembangan sistem surveilans sangat diperlukan untuk mendorong dokter praktek swasta ikut melaporkan kasus DBD yang ditemukan ditempat praktek mereka, sehingga kasus DBD yang dilaporkan akurat dan representative.

\section{METODE PENELITIAN}

Metode evaluasi sistem surveilans dilakukan secara kualitatif meliputi input, proses, dan output dan berdasarkan atribut surveilans.Pengembangan sistem surveilans 
menggunakan metode intervensi dengan mengidentifikasi, mengadvokasi, dan menbagikan formulir KD/RS DBD kepada 12 praktek dokter swasta yang ikut dalam pengembangan sistem surveilans DBD.

\section{HASIL PENELITIAN}

\section{INPUT}

\section{Masalah Sumber Daya Manusia} (Ketenagaan). Dari hasil wawancara yang dilakukakan, pelaksanaan surveilans mengalami kendala dalam jumlah tenaga yang masih dianggap masih kurang. Beban kerja yang dimiliki oleh petugas surveilans juga masih dinggap berat, karena 1 petugas surveilans memilki tugas rangkap sebagai perawat di Puskesmas juga. Petugas surveilans DBD juga bertugas untuk surveilans penyakit menular lainnya, seperti campak, diare, dan lain-lain, yang disebut sebagai Surveilans Terpadu (STP).

2. Pendanaan. Dana diperoleh dari alokasi APBD dengan pembagian disesuaikan terhadap kebutuhan program. Anggaran untuk program DBD hampir setiap tahun mengalami peningkatan. Hal ini menunjukkan adanya keseriusan pemerintahan Kota Denpasar dalam menangani penyakit terkait DBD. Anggaran untuk program pencegahan dan penaggulangan DBD beasar dari APBD. Rincian penggunan anggaran program
DBD termasuk adalah untuk honor koordinator jumantik dan jumantik.

3. Material (Diagnosis). Puskesmas I Denpasar Barat, penegakkan diagnosis DBD yaitu dengan pemeriksaan trombosit secara berkala sebanyak 3 kali. Misalnya pada pemeriksaan pertama trombosit pasien sebesar 200.000/ $\mu 1$, maka pasien kemudian disuruh untuk memeriksakan trombosit lagi pada hari berikutnya. Jika pada pemeriksaan ke-2

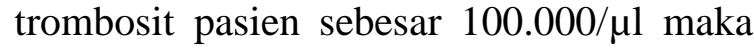
pasien akan di diagnosa DBD. Apabila trombosit pasien sebesar $\leq 100.000 / \mu 1$, maka pasien langsung dirujuk ke Rumah Sakit untuk penanganan lebih lanjut.

4. Sarana (Formulir) Berdasarkan studi dokumentasi yang dilakukan di Puskesmas I Denpasar Barat, formulir yang digunakan oleh puskesmas dalam penemuan kasus DBD di antaranya adalah form KD-PKM DBD, KD/RSDBD, Form Penyelidikan Epidemiologis (PE) dan hasil penyelidikan epidemiologis. Form KD-PKM DBD sudah terisi oleh puskesmas (100\%) mulai dari identitas pasien, tanggal mulai sakit, tanggal mulai dirawat, diagnosa awal, diagnosa akhir, dan hasil pemeriksaan laboratorium. Berdasarkan wawancara dengan petugas puskesmas bahwa begitu puskesmas dapat mendeteksi adanya tersangka DBD, maka petugas akan segera 
melapor ke Dinkes Kota Denpasar dalam waktu $1 \times 24$ jam dengan menggunakan form KD-PKM DBD. Begitu juga dengan form KD/RS- DBD sudah 100\% diisi. Form Penyelidikan Epidemiologis (PE) dan hasil penyelidikan PE meliputi tanggal lapor, unit lapor, nama tersangka DBD, alamat, Desa/Kelurahan, tanggal dilakukan PE, tanggal penyuluhan, tanggal fogging, tanggal abatesasi, $\mathrm{ABJ}$, nilai trombosit dan HCT, tanggal pelaksanaan, petugas pelaksana dan mengetahui tanda tangan kepala puskesmas juga telah diisi $100 \%$ yang artinya tidak ada satu kolom pun yang tak terisi/kosong.

\section{PROSES}

Pengumpulan dan pelaporan data. Pengumpulan dan pencatatan data di Puskesmas I Denpasar Barat dilakukan setiap hari, bila ada laporan tersangka DBD (Demam Berdarah Dengue) dan penderita DD (Demam Dengue), DBD, SSD (Sindrom Syok Dengue). Data tersangka DBD dan penderita DD, DBD, SSD yang diterima puskesmas hanya berasal dari Puskesmas sendiri, Rumah Sakit dan Dinas Kesehatan Kota, sedangkan pelaporan dari unit pelayanan kesehatan lain (dokter praktek swasta, poliklinik, dan lain-lain) belum ada. Selain itu juga pengumpulan data berasal dari penyelidikan epidemiologi (PE) yang dilakukan oleh jumantik.
Penyelidikan Epidemiologi yang dilakukan oleh jumantik, yaitu dengan melakukan observasi lapangan dari kasus yang dilaporkan oleh RSUD dan RS swasta dan mengisi formulir PE yang sudah disedikan oleh Dinas Kesehatan Kota Denpasar. Formulir PE yang sudah terisi kemudian diserahkan dan direkap oleh koordinator jumantik, setelah itu diserahkan ke petugas surveilans DBD di Puskesmas I Denpasar Barat. Data hasil PE trsebut kemudian dilaporkan ke Dinas Kesehatan Kota Denpasar. Pelakanaan PE di tingkat puskesmas diawasi oleh petugas surveilans DBD di Dinas Kesehatan Kota Denpasar.

Dari 12 praktek dokter swasta yang harus teridentifikasi, hanya 10 dokter yang berhasil ditemukan oleh peneliti. Peneliti sudah berusaha untuk menemukan 2 dokter tersebut yaitu dokter dengan kode 008 dan 009, dengan menanyakan ke penduduk setempat, akan tetapi mereka tidak mengetahui. Hal ini disebabkan dokter tersebut pindah tempat praktek 
Tabel L. Hasil Identifikasi Praktek Dokter Swasta

\begin{tabular}{|l|l|l|l|l|}
\hline No. & Kode Dokter & Alamat & Status & Keterangan \\
\hline 1. & 001 & Desa Tegal & Teridentifikasi & \\
\hline & & Harum & & \\
\hline 2. & 002 & Desa Tegal & Teridentifikasi & \\
\hline & & Kerta & & \\
\hline 3. & 003 & Kelurahan & Teridentifikasi & \\
\hline & & Padangsambian & & \\
\hline 4. & 004 & Desa Tegal & Teridentifikasi & \\
\hline & & Kerta & & \\
\hline 5. & 005 & Desa & Teridentifikasi & \\
\hline & & Padangsambian & & \\
\hline & & Kaja & & \\
\hline 6. & 006 & Desa & Teridentifikasi & \\
\hline & & Padangsambian & & \\
\hline & & Kaja & & \\
\hline 7. & 007 & Desa & Teridentifikasi & \\
\hline & & Padangsambian & & \\
\hline & & Kaja & & \\
\hline 8. & 008 & Desa Tegal & Tidak berhasil & Pindah tempat \\
\hline & & Kerta & teridentifikasi & praktek \\
\hline 9. & 009 & Desa Tegal & Tidak berhasil & Pindah tempat \\
\hline & & Kerta & teridentifikasi & praktek \\
\hline 10. & 010 & Kelurahan & Teridentifikasi & \\
\hline & & Padangsambian & & \\
\hline 11. & 011 & Desa Tegal & Teridentifikasi & \\
\hline & & Harum & & \\
\hline 12. & 012 & Desa Tegal & Teridentifikasi & \\
\hline & & & & \\
\hline
\end{tabular}

\section{Advokasi dan membagikan form KD/RS DBD Praktek Dokter Swasta}

Dari 10 praktek dokter swasta yang diadvokasi dan dibagikan form KD/DBD hanya 7 dokter yang berhasil peneliti temui langsung dan dijelaskan pengembangan sistem surveilans yang peneliti lakukan, sedangkan 3 dokter hanya dijelaskan kepada petugas apotek dan perawat yang bertugas di tempat praktek dokter yang bersangkutan. Hal ini disebkan karena 3 doktek tersebut boleh ditemui apabila semua pasien yang berkunjung selesai ditangani. Karena keterbatasan waktu dan peneliti harus menemui dokter yang lainnya, sehingga hanya dijelaskan dan dibagikan form KD/DBD kepada petugas apotek atau perawatnya untuk disampaikan kepada dokter yang bersangkutan. Doktek praktek swasta diharuskan melaporkan kasus DBD dengan mengisi form KD/RS DBD dan menghubungi nomor kontak peneliti yang tetera di dalam form tersebut. Berikut data dokter yang berhasil diadvokasi dan dibagikan form KD/RS DBD

\section{Kasus DBD yang dilaporkan oleh Dokter Praktek Swasta}

Setelah teridentifikasi, teradvokasi, dan terbagikan form KD/DBD ke praktek dokter swasta, peneliti mengidentifikasi jumlah laporan kasus DBD selama 3 bulan oleh dokter praktek swasta. Berikut jumlah kasus yang dilaporkan setiap minggu selama tiga bulan.

Tabel 2. Kasus DBD dari praktek dokter swasta yang dilaporkan setiap minggu pada bulan September-November 2019

\begin{tabular}{|c|c|c|c|c|c|c|c|c|c|}
\hline \multirow{2}{*}{ I0 } & \multirow{2}{*}{ Gode Dobter } & \multicolumn{8}{|c|}{ Bena } \\
\hline & & & Septen & & & totoler & More & enter & \\
\hline & & 1 & 23 & & $1 \%$ & 234 & 11 & 23 & 4 \\
\hline 1 & OOI & 0 & 01 & 0 & 00 & 000 & 100 & 00 & 0 \\
\hline 2 & 002 & 0 & 01 & 10 & 01 & 000 & 100 & 00 & 0 \\
\hline 3 & 003 & 0 & 01 & 0 & 0 & 000 & 100 & 0.0 & 0 \\
\hline 4 & ONA & i & 01 & 0 & 0. & 000 & 00 & 00 & 0 \\
\hline 5 & WS & 0 & 01 & 0 & 0 & 000 & 100 & 00 & 0 \\
\hline 6 & 006 & 0 & 01 & 0 & 0 & 000 & 100 & 01 & 0 \\
\hline 7 & 007 & 0 & 01 & 10 & 01 & 000 & 100 & 01 & 0 \\
\hline 8 & 010 & 0 & 0 & 10 & 0. & 000 & 100 & 01 & 0 \\
\hline 9 & Q11 & $\theta$ & 0 & 10 & 0 & 000 & 100 & 01 & 0 \\
\hline 10 & 012 & $\theta$ & 0 & 10 & 0 & 000 & 100 & 01 & l \\
\hline
\end{tabular}


Setelah melakukan evalusi selama 3 bulan, tidak ada satupun dokter praktek swasta yang melaporkan kasus DBD sehingga laporan kasus berjumlah o (nol). Tidak ada atau rendahnya pelaporan kasus DBD oleh dokter praktek swasta sejalan dengan pengembangan implementasi surveilans DBD yang dilakukan oleh Pitriyanti (2016) dimana hasilnya hanya 2 kasus yang dilaporkan oleh dokter praktek swasta. Hasil dari wawancara peneliti dengan Pitriyanti, bahwa rendahnya pelaporan kasus DBD oleh praktek dokter swasta dikarenakan oleh banyak faktor, diantaranya adalah peneliti tidak berusaha untuk mengingatkan kembali dokter praktek swasta untuk melaporkan kasus DBD dan kedekatan kekerabatan dengan dokter swasta sangat berpengaruh terhadap pelaporan kasus DBD, dimana Pitriyanti mengaku bahwa 2 kasus yang dilaporkan adalah kasus DBD yang berasal dari dokter praktek swasta yang kenal baik dengan Pitriyanti.

Tidak adanya kasus DBD yang dilaporkan disebabkan diantaranya adalah: pada saat membagikan formn KD/DBD kepada dokter, ada beberapa dokter yang menyatakan bahwa apabila ada kasus DBD mereka langsung merujuknya ke Rumah sakit, dan bila ditemukan suspect DBD akan disarankan melakukan pemeriksaan darah di Laboratorium, setelah itu biasanya pasien akan langsung ke Rumah Sakit. Ada juga Dokter yang menyatakan bahwa sekarang masyarakat sudah pintar, jika ada anggota keluarganya yang panas lebih dari 3 hari, mereka akan langsung membawanya ke Rumah sakit dan tidak dibawa ke praktek Dokter Swasta. Penyebab lainnya kemungkinan dokter tidak ada waktu karena banyaknya pasien yang harus ditangani untuk mengisi form $\mathrm{KD} / \mathrm{DBD}$ dan menghubungi peneliti untuk pelaporan kasus DBD. Selain itu juga karena praktek dokter swasta merasa tidak berkewajiban untuk melaporkan kasus DBD kepada pihak puskesmas.

Kelemahan dari pengembangan sistem surveilans DBD ini adalah, peneliti tidak berusaha untuk mengingatkan kembali dokter praktek swasta yang diadvokasi untuk melaporkan kasus DBD, sehingga ada kemungkinan dokter praktek swasta lupa untuk menghubungi penelti dalam melaporkan kasus

\section{KESIMPULAN}

Pengembangan sistem surveilans untuk pelaporan kasus DBD oleh praktek doktek swasta tidak berhasil dalam menjadikan data kasus DBD yang lebih akurat dan representatif. Hal ini disebabkan karena praktek dokter swasta yang berjumlah 10 orang, selama 3 bulan tidak ada yang 
melaporkan kasus DBD ke Puskesmas I

Denpasar Barat

\section{DAFTAR PUSTAKA}

Azmin, N., Rahmawati, A., \& Hidayatullah, M. E. (2019). Uji kandungan fitokimia dan etnobotani tumbuhan obat tradisional berbasis pengetahuan lokal di kecamatan Lambitu kabupaten Bima. Florea: $J \quad$ Biol Pembelajarannya, 6, 101-113

Azmin, N. N. (2019). Inventarisasi Tumbuhan Obat Tradisional Di Kecamatan Wera Kabupaten Bima. Oryza Jurnal Pendidikan Biologi, 8(2), 34-39

Azmin, N., \& Rahmawati, A. (2019). Skrining Dan Analisis Fitokimia Tumbuhan Obat Tradisional Masyarakat Kabupaten Bima. Jurnal Bioteknologi \& Biosains Indonesia (JBBI), 6(2), 259-268

Centre for Desease Control and Prevention (CDC). 2001. Updated Guidlines for Evaluating Public Health Surveilance System.

Depkes, R.I., 2005. Pencegahan dan Pemberantasan Demam Berdarah Dengue di Indonesia. Jakarta:Direktorat Jenderal PP \& PL.

Dinkes Kota Denpasar . 2016. Laporan Surveilans DBD di Wilayah Kerja Puskesmas Denpasar Barat I. P2P DBD Dinas Kesehatan Kota Denpasar .

Kemenkes. 2003. Pedoman Penyelenggaraan Sistem Surveilans Epidemiologi penyakit Menular Dan Penyakit Tidak Menular Terpadu. Kemenkes RI

Mahfudhoh, B. 2015. Komponen Sistem Surveilans Demam Berdarah Dengue (DBD) Di Dinas Kesehatan Kota Kediri. Artikel Ilmiah. FKM Universitas Airlangga. Surabaya.

Sitepu, Frans.Y., Suprayogi, A., Pramono, D. 2012. Evaluasi dan Implementasi Sistem Surveilans Demam Berdarah Dengue (DBD) di Kota Singkawang, Kalimantan
Barat. Artikel Vol. 8. Yogyakarta: Universitas Gadjah Mada

Sri Wulandari, Wiwit. 2009. Evaluasi Pelaksanaan Program Pencegahan dan Penanggulangan Penyakit Demam Berdarah Dengue Dinkes Kabupaten Magetan Tahun 2008. Skripsi. Surakarta: Universitas Sebelas Maret

Zumaroh.2013. Evaluasi Pelaksanaan Surveilans Kasus Demam Berdarah Dengue Di Puskesmas Putat Jaya Berdasarkan Atribut Surveilans. Fakultas Kesehatan Masyarakat .Surabaya.Universitas Airlangga

Denbar, P.I., 2016. Profil puskesmas Denpasar Barat. , (65), pp.65-66 